\title{
Cost Recovery Rate Tarif Rumah Sakit dan Tarif INA-CBG's Berdasarkan Clinical Pathway pada Penyakit Arteri Koroner di RS Pemerintah A di Palembang Tahun 2015
}

\author{
Cost Recovery Rate of Hospital and INA-CBG's Tariff Based on Clinical Pathway of Coronary \\ Artery Disease in A Public Hospital, Palembang, 2015
}

\author{
Mardiah', Ronnie Rivany ${ }^{2}$ \\ ${ }_{1}^{1}$ Program Studi Magister IImu Kesehatan Masyarakat Fakultas Kesehatan Masyarakat Universitas Indonesia \\ ${ }^{2}$ Departemen Administrasi Kebijakan Kesehatan Universitas Indonesia \\ Korespondensi: Mardiah \\ e-mail: mardiah.ibrahimarsyad@gmail.com
}

\begin{abstract}
Abstrak
Adanya selisih negatif pada kasus Coronary Artery Disease (CAD) pada tindakan Percutaneous Coronary Intervention (PCI), mengindikasikan pembiayaan kesehatan masih terdapat kesenjangan antara tarif rumah sakit dengan tarif INA-CBG's. Penelitian ini bertujuan untuk melihat perbedaan cost recovery rate (CRR) tarif INA-CBG's dan tarif rumah sakit kasus CAD dengan PCI di RS A Palembang. Hasil penelitian menunjukkan berdasarkan cost of treatment berbasis clinical pathways pada severity level I CRR RS berada diatas CRR tarif INA-CBG's, sedangkan pada severity level II CRR RS lebih rendah dari CRR tarif INA-CBG'S. Pada severity level III CRR tarif INA-CBG's dengan utilisasi stent 1 dan 2 lebih tinggi dari CRR RS. Tarif INACBGs tidak memperhitungkan jumlah stent dalam setiap tindakan PCI. Perlu evaluasi metode penghitungan tarif INA-CBGs dari hospital base rate ke metode perhitungan cost of treatment berdasarkan clinical pathway, sehingga biaya operasional RS dapat dipenuhi dan tetap mampu berikan pelayanan yang bermutu.

Kata kunci : Cost Recovery Rate, Cost of Treatment,Clinical pathway, CAD, PCI,INA-CBG's

Abstract

The difference of cost negative in the case of Coronary Artery Disease (CAD) with Percutaneous Coronary Intervention (PCI), indicate health financing gap between of hospital rates and INA-CBG's rates. This study aimed to see the difference between the cost recovery rate (CRR) of hospital rates and INA-CBG's rates for CAD with PCI at A Hospital. The results showed that the cost of treatment based on clinical pathways at the severity level I had a higher CRR Hospital rates compared to INA-CBG'S CRR, whereas at the severity level II, Hospital CRR rate was lower than INA-CBG's CRR for the utility of less than 2 stents. At severity level III, CRR INA-CBGs' rates with utilization of 1 and 2 stents performed higher rates than the hospitals CRR. This was related to INA-CBG'S rate that did not take the magnitude of the stentulitizationinto account. It is necessary to improve INA-CBG's tarif development method from hospital base rate to clinical pathway-based cost of treatment in order to meet hospital operational cost and ensure the best quality of service. Keywords: Cost Recovery Rate, Cost of Treatment, Clinical pathway, CAD, PCI, INA-CBG's
\end{abstract}

\section{Pendahuluan}

Program JKN membawa dampak besar dalam pelayanan kesehatan di Indonesia. Diberlakukannya JKN, Indonesia telah menjadi era baru dalam metode pembayaran bagi banyak rumah sakit, dimana sebagian besar rumah sakit yang selama ini menggunakan mekanisme pembayaran Fee for Service (FFS) mulai beralih ke mekanisme pembayaran dengan klaim berdasarkan Indonesia Case Base Groups (INA-CBG's).

Perubahan pembiayaan dari FFS ke INA-CBGs membawa RS menghadapi kondisi yang bisa menjadi ancaman atau peluang. Peluang jika RS dapat memanfaatkan program JKN dengan baik sehingga selisih klaim bernilai positif karena mampu menyesuaikan dengan tarif INA-CBG's dan yang negatif karena belum mampu memberikan pelayanan yang efektif dan efisien sehingga menjadi ancaman terhadap pengelolaan keuangan RS (Hardiman, 2013).

Banyak keluhan dari rumah sakit bahwa Tarif INA-CBG's jauh dibawah biaya yang dikeluarkan rumah sakit, padahal anggaran BPJS pada 2014 disediakan nyaris 20 Triliun, jauh lebih besar dari Jamkesmas, hal tersebut harusnya menyenangkan rumah sakit (Purnawan, 2014). Pada kenyataannya sebagian besar rumah sakit masih mengalami selisih negatif antara klaim tarif rumah sakit dibandingkan dengan tarif INA-CBG's, sebagaimana yang tergambar dalam tabel selisih tarif pelayanan di beberapa rumah sakit di Sumatera Selatan.

Klaim pembiayaan pasien peserta JKN pada 2014 menunjukkan adanya selisih positif dan negatif atas biaya klaim RS A dengan Tarif INA-CBG's untuk rawat inap selama Tahun 2014 adalah sebesar 
Rp232.263.700. Sedangkan untuk Kasus CAD pada pasien rawat inap terdapat selisih negatif sebesar Rp 598.025.075. Bahkan untuk kasus CAD dengan tindakan PCI (Percutaneous Coronary Intervention) selisih negatif yang terjadi jauh lebih besar yaitu sebesar Rp876.512.398.

Tingginya selisih biaya negatif pada kasus CAD pada tindakan PCI, mengindikasikan pembiayaan kesehatan masih terdapat kesenjangan antara tarif rumah sakit dengan tarif INA-CBG's di rumah sakit pada tahun 2014, sehingga perlu dilakukan penelitian mengenai perhitungan Cost Recovery Rate (CRR), dengan membandingkan cost of treatment dengan tarif INA-CBG's dan tarif rumah sakit pada kasus CAD dengan tindakan PCI.

\section{Metodologi Penelitian}

Jenis penelitian ini merupakan penelitian kuantitatif dan kualitatif. Desain penelitian kuantitatif dengan pendekatan cross sectional untuk analisis biaya. Penelitian diawali dengan menentukan clinical pathway yang kemudian dilakukan penyusunan cost of treatment dari kasus CAD dengan tindakan PCI. Kemudian membandingkan cost of treatment yang telah tersusun dengan Tarif INA-CBG's dan cost of treatment dengan Tarif Rumah Sakit. Sedangkan penelitian kualitatif dilakukan dengan Focus Discussion Group(FGD) dan wawancara. Penelitian dilakukan di bagian rekam medis, bagian keuangan, ruang SIMRS di RS A Palembang. Penelitian dilaksanakan sejak bulan Januari -Maret 2015. Pengambilan data primer dilakukan dengan pengamatan langsung dari ruang admisi sampai ke ruang rawat inap Instalasi Brain and Heart Center, ruang Kateter Jantung serta melaksanakan wawancara dengan kelompok Staf Medis Penyakit Dalam Divisi Kardiovaskuler (Dokter Spesialis Penyakit Dalam Konsultan Kardiovaskuler) dan Kelompok Staf Medik Kardiologi (Dokter Spesialis Jantung dan Paru).

Data sekunder diperoleh dari pengisian formulir daftar isian untuk mengetahui pemakaian fasilitas dalam tindakan PCI pada pasien Penyakit Jantung Koroner selama bulan Januari sampai Maret tahun 2015 yang ada pada catatan Rekam Medis Pasien. Dikumpulkan pula informasi dari bagian keuangan untuk mengetahui biaya masing-masing variabel dan total yang dibayarkan selama masa perawatan.

Dari karakteristik dan lama hari rawat pasien serta penyakit penyerta dan penyulit, dilakukan pengelompokan berdasarkan clinical pathway yang disepakati. Kemudian data yang didapat diolah dan dihitung sesuai dengan tindakan berdasarkan metode penelitian sehingga diperoleh unit cost pelayanan dan kemudian dirangkum sebagai Cost of treatment CAD.

Unit cost yang diperlukan dalam kegiatan ini adalah yang terkait dengan kegiatan selama perawatan pasien CAD dengan PCI sesuai clinical pathway. Beberapa kegiatan langsung dirangkum menjadi satu unit cost kegiatan seperti tindakan PCI dan asuhan keperawatan.

Unit cost untuk obat dan alat kesehatan diperoleh dari daftar harga yang diberikan Instalasi Farmasi RS A Pa. Dalam kegiatan PCI utilisasi alat kesehatan yang berpengaruh dalam tindakan PCI adalah stent baik jumlah dan jenis yang dipasang. Cost of treatment adalah perhitungan biaya yang terkait dengan biaya langsung dan tak langsung yang dibutuhkan untuk melakukan perawatan/tindakan PCI sesuai dengan clinical pathway pada pasien CAD yang telah disepakati.

Penghitungan biaya dilakukan berdasarkan 3 (tiga) clinical pathway yang ada di atas. Selain itu penghitungan juga dibedakan berdasarkan akomodasi yang ada dan jumlah stent yang dipergunakan pada tindakan PCI yang dilakukan. Dari kesepakatan 3 clinical pathway untuk tindakan PCI pada pasien CAD di RS A, selanjutnya dilakukan perhitungan cost of treatment masing-masing clinical pathway tersebut.

Perhitungan cost of treatment dalam penelitian ini menggunakan metode Activity Based Costing + Double Distribution Method. Metode double distribution dipergunakan untuk menghitung biaya satuan per unit pelayanan. Setelah didapat unit cost masing-masing unit produksi maka dikalikan dengan utilisasinya berdasarkan activity based costing dengan penambahan biaya obat dan jasa medis juga asuhan keperawatan.

\section{Hasil Penelitian \\ Karakteristik Responden}

Karakteristik responden dalam penelitian ini dapat dilihat pada Tabel 1, dimana dari total 32 pasien yang diobservasi, mayoritas adalah lansia (60 tahun ke atas), berjenis kelamin laki-laki, dan merupakan peserta $(\mathrm{JKN})$ atau non-PBI.

Adapun penyakit penyerta yang diperhitungkan adalah penyakit yang jumlahnya paling banyak ditemukan dalam waktu pengambilan kasus penelitian yaitu 1) Dislipidemia (E. 789), 2) Hipertensive Heart Disease /HHD (I.119), 3) Hipertensi (I.10) dan 4) Diabetes Melitus (E119). Jenis penyakit pen- 
Tabel 1.Distribusi Frekuensi Karakteristik

Pasien CAD dengan Tindakan PCI

\begin{tabular}{|c|c|c|c|c|c|}
\hline No. & \multicolumn{4}{|c|}{ Karakteristik } & n (\%) \\
\hline \multirow[t]{4}{*}{1} & Umur (tahun) & \multicolumn{3}{|c|}{ Anak-anak (0-17) } & $0(0)$ \\
\hline & & \multicolumn{3}{|c|}{ Muda $(18-<45)$} & $1(3)$ \\
\hline & & \multicolumn{3}{|c|}{$\operatorname{Tua}(\geq 60)$} & $31(97)$ \\
\hline & & \multicolumn{3}{|c|}{ Total } & $32(100)$ \\
\hline \multirow[t]{3}{*}{2} & Jenis Kelamin & \multicolumn{3}{|c|}{ Laki-laki } & $22(69)$ \\
\hline & & \multicolumn{3}{|c|}{ Perempuan } & $10(31)$ \\
\hline & & \multicolumn{3}{|c|}{ Total } & $32(100)$ \\
\hline \multirow[t]{8}{*}{3} & \multirow{2}{*}{ Cara Bayar } & \multicolumn{3}{|c|}{ Kelas Rawat } & \\
\hline & & I & II & III & \\
\hline & PBI & - & - & - & - \\
\hline & Non-PBI & 24 & 5 & 1 & $30(93.8)$ \\
\hline & JAMKESDA & - & - & 2 & $2(6.2)$ \\
\hline & PRIBADI & - & - & - & - \\
\hline & Total Kasus & 24 & 5 & 3 & $32(100)$ \\
\hline & Persen (\%) & 79 & 16 & 9 & 100 \\
\hline
\end{tabular}

Tabel 2 Lama Hari Rawat Pasien CAD dengan PCI

\begin{tabular}{|c|c|c|c|c|c|c|c|c|c|c|}
\hline \multirow{2}{*}{ Diagnosa } & \multicolumn{7}{|c|}{ Lama Hari Rawat (hari) } & \multirow{2}{*}{$\begin{array}{l}\text { Total } \\
\text { (hari) }\end{array}$} & \multirow{2}{*}{$\begin{array}{l}\text { Mean } \\
\text { (hari) }\end{array}$} & \multirow{2}{*}{$\begin{array}{c}\text { Modus } \\
\text { (hari) }\end{array}$} \\
\hline & 3 & 4 & 5 & 6 & 7 & 8 & 12 & & & \\
\hline Murni & 1 & 1 & 1 & - & - & - & - & 12 & 4 & - \\
\hline Penyulit & 10 & 6 & 6 & 3 & - & 1 & - & 110 & 4,2 & 3 \\
\hline $\begin{array}{l}\text { Penyulit dan } \\
\text { Penyerta }\end{array}$ & 1 & - & - & - & 1 & 1 & 1 & 26 & 6,5 & - \\
\hline
\end{tabular}

yulit yang ditemui bersama penyerta yang ditemukan dalam rentang waktu pengambilan kasus penelitian yaitu Congestive Heart Failure (I.110) dan Infark Miokard (I.21.0). Tabel 2 menggambarkan jumlah hari rawat pasien berdasarkan jenis diagnosanya yang menunjukkan bahwa dibandingkan dengan Pasien CAD dengan tindakan PCI Murni dan Penyulit, pasien dengan Penyulit dan Penyerta memiliki
Length of Stay yang lebih lama.

Tabel 3 menunjukkan bahwa cost of treatment pasien CAD didominasi untuk operasi, disusul dengan pra dan post-operasi dimana nilainya semakin besar seiring dengan adanya penyerta dan penyulit.Cost Index merupakan persentase perhitungan dari total cost pada tiap tahapan dalam clinical pathway pasien Pada Tabel 3 dijelaskan bahwa CAD yang diba- 
Tabel 3 Cost of treatment (tanpa Akomodasi) berdasarkan Clinical pathway Pasien CAD dengan Tindakan PCI di RS A Palembang

\begin{tabular}{|c|c|c|c|c|c|c|}
\hline \multirow{2}{*}{ Kegiatan } & \multicolumn{2}{|c|}{ CAD Murni } & \multicolumn{2}{|c|}{ CAD Penyerta } & \multicolumn{2}{|c|}{$\begin{array}{c}\text { CAD Penyerta+Pen- } \\
\text { yulit }\end{array}$} \\
\hline & $(\mathrm{Rp})$ & (\%) & (Rp) & $(\%)$ & (Rp) & (\%) \\
\hline LOS & \multicolumn{2}{|c|}{3} & \multicolumn{2}{|c|}{3} & \multicolumn{2}{|c|}{6} \\
\hline Pendaftaran & 15.879 & 0,05 & 15.879 & 0,05 & 15.879 & 0,04 \\
\hline $\begin{array}{l}\text { Penegakan Diag- } \\
\text { nosa }\end{array}$ & 1.778 .375 & 5,64 & 1.778 .375 & 5,22 & 1.778 .375 & 4,91 \\
\hline Pra-Operasi & 174.289 & 0,55 & 1.399 .518 & 4,11 & 1.937 .078 & 5,35 \\
\hline Operasi & 29.284 .773 & 92,91 & 29.284 .773 & 86 & 29.284 .773 & 80,82 \\
\hline Post-Operasi & 195.087 & 0,62 & 1.445 .306 & 4,24 & 3.085 .435 & 8,52 \\
\hline Pulang & 69.652 & 0,22 & 129.085 & 0,38 & 132.564 & 0,37 \\
\hline COT & 31.518 .054 & 100 & 34.052 .935 & 100 & 36.234 .104 & 100 \\
\hline
\end{tabular}

Tabel 4 Cost Indeks (tanpa Akomodasi) berdasarkan Clinical pathway Pasien CAD dengan Tindakan PCI tanpa Perhitungan Jumlah Stent

\begin{tabular}{lccc}
\hline \multicolumn{1}{c}{ Kegiatan } & CAD Murni & CAD Penyerta & CAD Penyerta+Penyulit \\
& Cost Index (\%) & Cost Index (\%) & Cost Index (\%) \\
LOS & 3 & 3 & 6 \\
Pendaftaran & 0,05 & 0,05 & 0,04 \\
Penegakan Diagnosa & 5,64 & 5,22 & 4,91 \\
Pra Operasi & 0,55 & 4,11 & 5,35 \\
Operasi & 92,91 & 86 & 80,82 \\
Post Operasi & 0,62 & 4,24 & 8,52 \\
Pulang & 0,22 & 0,38 & 0,37 \\
COT & 100 & 100 & 100 \\
\hline
\end{tabular}

gi dengan cost of treatment yaitu CAD murni, CAD Penyerta dan CAD penyerta dan penyulit. Secara keseluruhan dalam kasus pasien CAD yang dilakukan tindakan PCI maka cost index terbesar berada dalam tahapan tindakan operasi PCI.

Cost Index merupakan persentase perhitungan dari total cost pada tiap tahapan dalam clinical pathway pasien $\mathrm{CAD}$ yang dibagi dengan cost of treatment. Pada tabel 4 dapat dilihat secara keseluruhan dalam kasus pasien CAD yang dilakukan tindakan PCI maka cost index terbesar berada dalam tahapan tindakan operasi PCI.
Tabel 5 menjelaskan bahwa dalam INA-CBG's terdapat Special CMG pada tarif INA-CBGs yang saat ini dibuat agar mengurangi resiko keuangan rumah sakit. Saat ini hanya diberikan untuk beberapa obat, alat-alat kesehatan, prosedur, pemeriksaan penunjang, kasus penyakit subakut dan kronis yang selisih tarif INA-CBGs dengan tarif rumah sakit masih cukup besar. Sedangkan saat ini kode special CMGYY03 tarifnya sesuai grouper versi 4.1 hanya bernilai Rp.18.600.200. Nilai tarif Prosedur PCI dalam tarif INA-CBGs sesuai kelas rawat dan penambahan special CMG. 


\begin{tabular}{|c|c|c|c|c|c|c|c|c|}
\hline \multirow{2}{*}{$\begin{array}{l}\text { Diagnosa } \\
\text { PCI Murni }\end{array}$} & \multirow{2}{*}{$\begin{array}{l}\text { Jumlah } \\
\text { Stent }\end{array}$} & \multirow{2}{*}{$\begin{array}{c}\text { LOS } \\
\text { (hari) }\end{array}$} & \multicolumn{2}{|c|}{ COT (Rp) } & \multicolumn{2}{|c|}{ Tarif INA-CBG (Rp) } & \multicolumn{2}{|c|}{ CRR (\%) } \\
\hline & & & Murni & $\begin{array}{l}\text { Dengan } \\
\text { Penyerta }\end{array}$ & Murni & $\begin{array}{l}\text { Dengan } \\
\text { Penyerta }\end{array}$ & Murni & $\begin{array}{l}\text { Dengan } \\
\text { Penyerta }\end{array}$ \\
\hline \multirow{4}{*}{ Kelas I } & Stent 1 & & 51.342 .045 & 53.876 .926 & & \multirow{4}{*}{82.969 .900} & 87 & 154 \\
\hline & Stent 2 & 3 & 69.838 .221 & 72.373 .101 & 44.640 .500 & & 64 & 115 \\
\hline & Stent 3 & & 88.334 .396 & 90.869 .276 & & & 51 & 91 \\
\hline & Stent 4 & & 106.830 .571 & 109.365 .452 & & & 42 & 76 \\
\hline \multirow[t]{4}{*}{ Kelas II } & Stent 1 & & 50.764 .230 & 53.299 .110 & & \multirow{4}{*}{73.774 .300} & 81 & 138 \\
\hline & Stent 2 & 3 & 69.260 .405 & 71.795 .285 & 40.920 .500 & & 59 & 103 \\
\hline & Stent 3 & & 87.756 .580 & 90.291 .461 & & & 47 & 82 \\
\hline & Stent 4 & & 106.252 .755 & 108.787 .636 & & & 39 & 68 \\
\hline \multirow[t]{4}{*}{ Kelas III } & Stent 1 & & 50.453 .730 & 52.988 .610 & & \multirow{4}{*}{64.578 .600} & 74 & 122 \\
\hline & Stent 2 & 3 & 68.949 .905 & 71.484 .785 & 37.198 .600 & & 54 & 90 \\
\hline & Stent 3 & & 87.446 .080 & 89.980 .961 & & & 43 & 72 \\
\hline & Stent 4 & & 105.942 .255 & 108.477 .136 & & & 35 & 60 \\
\hline
\end{tabular}

Tabel 6 Tarif INA-CBGs Pasien CAD denganTindakan PCI Penyerta + Penyulit

\begin{tabular}{|c|c|c|c|c|c|}
\hline $\begin{array}{c}\text { Diagnosa CAD Dengan Penyerta + } \\
\text { Penyulit }\end{array}$ & $\begin{array}{l}\text { Jumlah } \\
\text { Stent }\end{array}$ & LOS & COT & Tarif INA CBG & CRR (\%) \\
\hline \multirow{4}{*}{ Kelas I } & Stent 1 & 6 & 56.058 .095 & \multirow{4}{*}{104.584 .800} & 188 \\
\hline & Stent 2 & 6 & 74.554 .270 & & 138 \\
\hline & Stent 3 & 6 & 93.050 .445 & & 109 \\
\hline & Stent 4 & 6 & 111.546 .621 & & 67 \\
\hline \multirow{4}{*}{ Kelas II } & Stent 1 & 6 & 55.480 .279 & \multirow{4}{*}{92.294 .000} & 168 \\
\hline & Stent 2 & 6 & 73.976 .454 & & 122 \\
\hline & Stent 3 & 6 & 92.472 .630 & & 96 \\
\hline & Stent 4 & 6 & 110.968 .805 & & 59 \\
\hline \multirow{4}{*}{ Kelas III } & Stent 1 & 6 & 55.169 .779 & \multirow{4}{*}{82.969 .900} & 152 \\
\hline & Stent 2 & 6 & 73.665 .954 & & 111 \\
\hline & Stent 3 & 6 & 92.162 .130 & & 87 \\
\hline & Stent 4 & 6 & 110.658 .305 & & 53 \\
\hline
\end{tabular}

Dari hasil perbandingan tarif pada tabel 6 penulis kemudian mencoba menempatkan pengelompokan tarif RS dan INA-CBG's terhadap COT yang dianggap setara. Dari tarif INA-CBG's yang bisa kita hitung nilai CRR nya hanya untuk Pasien CAD dengan tindakan PCI Murni diasumsikan setara dengan tindakan perkutaneus ringan. Sedangkan den- gan penyerta dianggap setara dengan tindakan PCI sedang dan yang tertinggi CAD dengan penyerta penyulit dianggap setara dengan tindakan PCI berat. Sedangkan perbedaan harga stent tidak dapat diukur. Hal ini dikarenakan tidak adanya kejelasan pengelompokkan kriteria ringan, sedang dan berat pada pola tarif INA-CBG's. 
Tabel 7 Perbandingan CRR Tarif RS dan Tarif INA-CBGs pasien Kelas I, II, III berdasarkanCost of treatment berbasis Clinical pathway Pasien CAD dengan Tindakan PCI Murni, dengan Penyerta, serta Penyulit dan Penyertadi RS A Palembang Tahun 2015

\begin{tabular}{lccccccc}
\hline & $\begin{array}{c}\text { JUMLAH } \\
\text { STENT }\end{array}$ & LOS & $\begin{array}{c}\text { COT } \\
(\mathbf{R p})\end{array}$ & $\begin{array}{c}\text { TARIF RS } \\
(\mathbf{R p})\end{array}$ & CRR (\%) & $\begin{array}{c}\text { TARIF INA CBG } \\
(\mathbf{R p})\end{array}$ & CRR (\%) \\
\hline MURNI & 3 & 3 & 93.895 .871 & 87.973 .106 & 94 & 44.640 .500 & 48 \\
\hline Kelas I & 3 & 4 & 93.318 .055 & 88.534 .317 & 95 & 40.920 .500 & 44 \\
\hline Kelas II & 1 & 3 & 55.504 .350 & 56.030 .356 & 101 & & 149 \\
\hline PENYERTA & 2 & 3 & 75.854 .350 & 73.389 .245 & 97 & & 109 \\
\hline & 3 & 3 & 96.204 .350 & 143.607 .728 & 149 & 82.969 .900 & 86 \\
Kelas I & 4 & 3 & 157.254 .350 & 96.811 .727 & 62 & & 53 \\
\hline Kelas II & 1 & 6 & 54.994 .996 & 58.832 .588 & 107 & 73.374 .100 & 100 \\
\hline \multicolumn{2}{l}{ PENYERTA \& PENYULIT } & & & & & & \\
\hline Kelas II & 3 & 3 & 95.694 .996 & 88.139 .598 & 92 & 92.294 .000 & 96 \\
Kelas III & 1 & 12 & 54.684 .496 & 66.182 .799 & 121 & 82.969 .900 & 152 \\
\hline
\end{tabular}

\section{Pembahasan}

Berdasarkan hasil penelitian, dalam penulisan diagnosis yang tertera didalam rekam medis biasa dilakukan oleh dokter dan hasilnya tidak selalu sama dan sesuai dengan diagnosa yang dipilih coder atau petugas rekam medis. Dari data yang diperoleh selama penelitian, diagnosa Coronary Artery Disease termasuk dalam pengkodean ICD X yaitu I.25.1 Atherosclerotic heart disease masuk dalam MDC 5 Disease and Disorder of the circulatory system.

Berdasarkan wawancara dengan petugas rekam medis, dokter penanggung jawab pasien dan perawat ruangan, pada umumnya dokter tidak pernah menulis diagnosa berdasarkan pengkodean ICD X. Pengkodean ICD dilakukan oleh petugas rekam medis. Hal ini sejalan dengan beberapa penelitian terdahulu yang menyebutkan bahwa pencatatan rekam medis di rumah sakit masih belum baik, baik dari segi kelengkapan maupun pemahaman tentang ICD-X (Suryati, 1998, Muchlis, 2014).

Pada Tabel 2 menunjukkan bahwa kelompok penyakit CAD dengan diagnosa murni dan CAD dengan penyerta memiliki lama hari rawat yang hampir sama. Hal ini disebabkan oleh penyakit penyerta pada pasien CAD yang pada prinsipnya merupakan faktor risiko kejadian CAD sendiri seperti dislipidemia, hipertensi, koagulasi dan diabetes melitus, sehingga penatalaksanaan perawatan dan pengobatan yang lebih kurang sama. Namun, penderita CAD dengan penyerta dan penyulit memiliki lama hari rawat yang lebih panjang, disebabkan adanya penat- alaksanaan terhadap penyulit yang muncul.

Clinical pathway disusun dari data rekam medis yang dikumpulkan sehingga menjadi suatu draft dengan sesuai pedoman yang terdiri dari pendaftaran, penegakkan diagnosa, pra-terapi (pra-operasi), terapi (operasi), tindak lanjut, dan pulang. Diskusi dilakukan sampai tersusun suatu clinical pathway yang disepakati dan dapat digunakan untuk kasus CAD dengan tindakan PCI.

Hasil penelitian menunjukkan bahwa penanganan pasien kasus CAD dengan tindakan PCI dapat dilakukan selama 3 hari untuk pasien CAD murni dan CAD dengan penyerta, secara umum telah dilakukan para dokter, tetapi sebagian masih melebihi waktu yang telah ditetapkan tersebut. Dari rata-rata 3 hari tersebut dapat dilihat besaran biaya pelayanan yang ditimbulkan jika melebihi masa rawat tersebut semakin besar biaya yang dikeluarkan dan menunjukkan bagaimana efisiensi layanan yang diberikan. Hal ini sesuai dengan tujuan clinical pathway yaitu sebagai alat ukur efisiensi dalam pelayanan kesehatan. Sesuai dengan penelitian Dewi Indah (2015) yang menunjukkan bahwa dengan adanya penatalaksanaan pasien melalui clinical pathway beserta utilisasinya maka biaya dapat dihitung sesuai dengan kondisi dan kelompok diagnosis suatu penyakit.

Dalam penelitian ini, unit cost yang mendukung kegiatan pelayanan kasus CAD dengan tindakan PCI diperoleh dari unit cost rumah sakit yang disusun pada tahun 2012, padahal idealnya disusun berdasarkan unit cost yang sudah disesuaikan dengan 
data tahun terakhir.

Dari unit cost yang menyusun biaya pelayanan tindakan PCI pada pasien CAD ternyata unit cost tertinggi adalah unit cost layanan tindakan PCI, yaitu sebesar Rp 29.284.773, sedangkan dalam tiap tindakan PCI terdapat utilitasi stent yang bernilai rata-rata Rp18.496.175 per satuannya, dimana jenis stent yang digunakan pada seluruh sampel penelitian adalah DES (drug eluting stent).

Dalam penelitian ini, cost of treatment dari pasien CAD dengan tindakan PCI bervariasi sesuai 3 clinical pathway yang telah disepakati, semakin berat derajat keparahan penyakit, semakin besar COT yang dihasilkan. Pasien CAD yang menjalani PCI tanpa penyerta dan penyulit, besar COT hanya Rp 31.518.054, sedangkan dengan penyerta bernilai $\mathrm{Rp}$ 34.052.935 dan CAD dengan penyerta dan penyulit nilai COT meningkat menjadi Rp 36.234.104. Hal ini disebabkan adanya perbedaan dalam pemeriksaan penunjang yang dilakukan, obat-obatan yang digunakan, serta lamanya hari rawat. Selain itu, jenis kelas rawat juga berpengaruh terhadap besar COT (Muchlis, 2014), seperti pasien Kelas I yang akan mengalami pengingkatan nilai pada tahapan discharge sehingga akan mempengaruhi nilai COT secara keseluruhan.

Dalam penelitian ini, COT tertinggi ada pada kelas rawat yang paling tinggi dan pada CAD dengan penyulit dan penyerta dimana akomodasi yang ditambahkan menjadi 6 kali akomodasi kelas I ditambah utilisasi stent sebanyak 4 buah sehingga nilai COT mencapai Rp112.874.436, sedangkan CAD murni dengan tindakan PCI pada ruang perawatan kelas III dengan utilisasi stent hanya 1 buah nilai COT hanya mencapai Rp51.342.045.

Berdasarkan studi ini, tahapan terapi (operasi) mempunyai proporsi terbesar dari total COT (92,91\%) baik pada kelompok penyakit murni, penyerta, maupun kelompok komplikasi dan penyerta. Hal ini juga terbukti di beberapa rumah sakit lainnya, seperti appendiktomi murni di RSU Kab. Tangerang (2014), Herniotomi Murni di PMI Bogor (2013), dan Ca Payudara Murni Bedah MRM RS Kanker Dharmais (2008) yang menghabiskan masing-masing $77,67 \%, 73,9 \%$, dan $76,8 \%$.

Dengan kata lain, dibanding dengan RS lain, unit cost tindakan PCI yang terdapat di RS A Palembang cukup tinggi. Penggunaan stent yang mahal dalam tindakan PCI juga sangat mempengaruhi besaran cost of treatment. Semakin banyak stent yang digunakan maka akan semakin besar nilai cost of treat- ment yang muncul dan akan mempengaruhi persentase cost index tahapan tersebut. Berdasarkan PMK nomor: 100/PMK.05/2014 dan SK Direktur, penggunaan satu stent (DES) memiliki tarif sebesar Rp55.000.000, sedangkan empat stent (DES) sebesar Rp96.000.000.

Tarif INA-CBG's yang digunakan dalam pengklaiman pasien BPJS di RS A Palembang adalah Tarif INA-CBG's versi 4.1. Dalam aplikasi terakhir INA-CBG's yaitu sistem INA-CBG's versi 4.1 terjadi peningkatan dan penurunan nilai tarif. Top-up tersebut pada PCI bernilai sama pada semua severity level dan pada semua kelas, untuk Regional 2 RS tipe A bernilai Rp 18.600.200 (PMK 59 th.2014). Nilai spesial prosedur PCI termasuk yang mengalami penurunan nilai tarif, dimana dari sebelumnya bernilai Rp19.476.681.

Tarif INA-CBG's tidak melihat besaran jumlah alat medis ataupun alat habis pakai yang digunakan dalam tindakan PCI, ini ditunjukkan dari seragamnya nilai top-up tindakan PCI pada semua severity level dan pada semua kelas. Perbedaan metode penghitungan biaya dalam menentukan tarif rumah sakit adalah berdasarkan hospital base rate. Hal ini sesuai dengan penelitian Dewi (2013) dan Muchlis (2014) yang menyebutkan sulitnya menerapkan pengelompokkan tarif berdasarkan INA-CBG's karena perbedaan pengelompokkan dengan tarif RS.

Dalam pengelolaan suatu rumah sakit baik pemerintah maupun swasta, nilai CRR diatas 100\% merupakan tujuan yang ingin dicapai. Hal ini artinya total biaya yang dikeluarkan dapat ditutupi seluruhnya dengan biaya penerimaan rumah sakit. Nilai CRR memperlihatkan seberapa besar subsidi yang harus diberikan pada suatu rumah sakit. Hasil penelitian memperlihatkan untuk kategori pasien BPJS dengan tarif INA-CBG's, pada tiap diagnosa yang berbeda dengan utilisasi yang berbeda maka muncul nilai CRR yang berbeda. Semakin banyak jumlah stent yang digunakan maka semakin kecil nilai CRR yang dihasilkan.

Nilai CRR tarif INA-CBG's yang ada untuk kasus CAD murni pada pasien kelas I sampai kelas III secara umum berada dibawah angka 90\% untuk 1 stent dan kecenderungannya semakin kecil jika stent yang dipergunakan meningkat sampai 4 stent. Sedangkan untuk kasus CAD dengan Penyerta yang dilakukan tindakan PCI secara umum jika pemakaian stent mencapai 2 stent maka CRR masih berada diatas $100 \%$, namun jika stent yang digunakan sudah mencapai 3 stent maka CRR rata-rata berada pada 
kisaran 90\%. Jika stent yang digunakan 4 buah maka CRR hanya mencapai 50\% bahkan kurang atau lebih. Pada kasus CAD dengan Penyertadan Penyulit untuk tindakan PCI yang menggunakan 1dan 2 stent baik pada kelas I sampai kelas III rata-rata CRR berada diatas 100\%. Hal ini disebabkan utilisasi stent menghabiskan biaya cukup besar, sedangkan topup pada spesial prosedur PCI hanya diperkenankan satu kali dengan nilai yang sama disetiap kelas yaitu sebesar Rp18.600.200 padahal unit cost yang dikeluarkan oleh rumah sakit untuk setiap stent adalahRp18.496.175 per satuannya.

Adapun CRR yang dapat diperbandingkan adalah tindakan PCI pada CAD murni di kelas rawat I dan kelas III dengan utilisasi stent sebanyak 3 buah, tarif RS menunjukkan CRR mendekati 100\% sedangkan tarif INA-CBG's hanya mencapai $50 \%$. Untuk perbandingan CRR pada pasien CAD dengan Penyulit dan Penyerta dikelas II dengan utilisasi stent 3 CRR Tarif RS mencapai 92\% sedangkan tarif INA-CBG's mencapai $100 \%$. Pada pasien kelas III dengan utilisasi stent 1 buah CRR tarif RS mencapai 119,01\% sedangkan dari tarif INA-CBG's mencapai 149\%.

Dalam penelitian ini dilakukan analisis sensitivitas yang dimaksudkan untuk mencari nilai maksi- mal dari perubahan komponen penyusun unit cost sehingga dapat memberikan penilaian yang berbeda dari tarif yang diperbandingkan. Sebagai rumah sakit pemerintah, biaya investasi berupa bangunan dan peralatan serta gaji PNS mendapatkan bantuan biaya dari APBN, sehingga untuk melihat sensitivitas dalam penelitian ini dalam perhitungan unit cost biaya investasi dikeluarkan untuk melihat besaran CRR tanpa investasi dan CRR tanpa investasi dan tanpa gaji PNS dengan mengeluarkan biaya investasi dan gaji PNS dalam perhitungan unit cost.

Tabel 8, perbandingan CRR Tarif INA-CBG's dan Tarif Rumah Sakit terhadap COT dengan Investasi dan Gaji PNS, COT Tanpa Investasi serta COT tanpa Investasi dan gaji PNS metunjukkan bahwa jika biaya investasi dikeluarkan maka CRR tarif INACBG's dan CRR tarif rumah sakit menunjukkan nilai yang lebih baik, kecenderungan mencapai nilai 100\% lebih, kecuali utilisasi stent 3 pada kelompok penyakit CAD dengan PCI Murni maka CRR tarif INA-CBG's masih berkisar diangka 47\%- 56\%. Hal ini menunjukkan nilai stent masih tetap memegang peranan penting dalam menentukan besarnya cost of treatment baik tanpa mempehitungkan nilai investasi maupun dengan memperhitungkan nilai investasi.

Tabel 8 Tabel Perbandingan CRR Tarif INA-CBGs dan Tarif Rumah Sakit terhadap COT dengan Investasi dan Gaji PNS, COT Tanpa Investasi serta COT Tanpa Investasi dan gaji PNS

\begin{tabular}{|c|c|c|c|c|c|c|c|c|c|c|c|c|c|}
\hline \multirow[b]{2}{*}{$\begin{array}{c}\text { Klasifikasi CAD } \\
\text { dengan PCI }\end{array}$} & \multirow[b]{2}{*}{ Stent } & \multirow[b]{2}{*}{ LOS } & \multirow[b]{2}{*}{ Tarif RS } & \multirow[b]{2}{*}{ INA-CBGs } & \multicolumn{3}{|c|}{ COT } & \multicolumn{3}{|c|}{ CRR Rumah Sakit } & \multicolumn{3}{|c|}{ CRR INA-CBGS } \\
\hline & & & & & $\begin{array}{c}\text { Investasi } \\
\text { Dan Gaji } \\
\text { PNS } \\
\text { Dihitung }\end{array}$ & $\begin{array}{c}\text { Biaya } \\
\text { Investasi } \\
\text { Tidak } \\
\text { Dihitung }\end{array}$ & $\begin{array}{c}\text { Biaya } \\
\text { Investasi } \\
\text { Dan Gaji } \\
\text { PNS Tidak } \\
\text { Dihitung }\end{array}$ & $\begin{array}{c}\text { Investasi } \\
\text { Dan Gaji } \\
\text { PNS } \\
\text { Dihitung }\end{array}$ & $\begin{array}{c}\text { Biaya } \\
\text { Investasi } \\
\text { Tidak } \\
\text { Di- } \\
\text { hitung }\end{array}$ & $\begin{array}{c}\text { Biaya } \\
\text { Investasi } \\
\text { Dan Gaji } \\
\text { PNS } \\
\text { Tidak } \\
\text { Dihitung }\end{array}$ & $\begin{array}{l}\text { Investasi } \\
\text { Dan } \\
\text { Gaji } \\
\text { PNS Di- } \\
\text { hitung }\end{array}$ & $\begin{array}{c}\text { Biaya } \\
\text { Investasi } \\
\text { Tidak } \\
\text { Dihitung }\end{array}$ & $\begin{array}{c}\text { Biaya } \\
\text { Investasi } \\
\text { Dan Gaji } \\
\text { PNS } \\
\text { Tidak } \\
\text { Dihitung }\end{array}$ \\
\hline Murni Kelas I & 3 & 3 & 87.973.106 & 44.640 .500 & 88.334 .396 & 86.174 .132 & 79.407 .050 & $99,59 \%$ & $102,09 \%$ & $110,79 \%$ & $51 \%$ & $52 \%$ & $56 \%$ \\
\hline Murni Kelas II & 3 & 4 & 88.534 .317 & 40.920 .500 & 87.756 .580 & 85.344 .356 & 78.829 .234 & $100,89 \%$ & $103,74 \%$ & $112,31 \%$ & $47 \%$ & $48 \%$ & $52 \%$ \\
\hline $\begin{array}{c}\text { Penyerta } \\
\text { Kelas I }\end{array}$ & 1 & 3 & 56.030 .356 & 82.969 .900 & 53.876 .926 & 51.324 .975 & 44.400 .219 & $104,00 \%$ & $109,2 \%$ & $126,2 \%$ & $154 \%$ & $162 \%$ & $187 \%$ \\
\hline $\begin{array}{c}\text { Penyerta } \\
\text { Kelas I }\end{array}$ & 2 & 3 & 73.389 .245 & 82.969 .900 & 72.373 .101 & 69.821 .150 & 62.896 .394 & $101,40 \%$ & $105,1 \%$ & $116,7 \%$ & $115 \%$ & $119 \%$ & $132 \%$ \\
\hline $\begin{array}{c}\text { Penyerta } \\
\text { Kelas I }\end{array}$ & 3 & 3 & 88.450 .637 & 82.969 .900 & 90.869 .276 & 88.317 .325 & 81.392 .569 & $97,34 \%$ & $100,2 \%$ & $108,7 \%$ & $91 \%$ & $94 \%$ & $102 \%$ \\
\hline $\begin{array}{c}\text { Penyerta } \\
\text { Kelas I }\end{array}$ & 4 & 3 & 96.811 .727 & 82.969 .900 & 109.365 .452 & 106.813 .501 & 99.888 .745 & $88,52 \%$ & $90,6 \%$ & $96,9 \%$ & $76 \%$ & $78 \%$ & $83 \%$ \\
\hline $\begin{array}{l}\text { Penyerta } \\
\text { Kelas II }\end{array}$ & 1 & 6 & 58.832 .588 & 73.774 .300 & 53.299 .110 & 50.341 .663 & 43.822 .403 & $110,38 \%$ & $116,9 \%$ & $134,3 \%$ & $138 \%$ & $147 \%$ & $168 \%$ \\
\hline $\begin{array}{l}\text { Penyerta } \\
\text { Kelas III }\end{array}$ & 2 & 3 & 69.304 .504 & 64.578 .600 & 71.484 .785 & 68.527 .339 & 62008078,32 & $96,95 \%$ & $101,1 \%$ & $111,8 \%$ & $90 \%$ & $94 \%$ & $104 \%$ \\
\hline $\begin{array}{l}\text { Penyerta+Pen- } \\
\text { yulit Kelas II }\end{array}$ & 3 & 6 & 88.139 .598 & 92.294 .000 & 93.222 .630 & 90.452 .350 & 83.428 .059 & $94,55 \%$ & $97,44 \%$ & $105,65 \%$ & $99 \%$ & $102,04 \%$ & $110,63 \%$ \\
\hline $\begin{array}{l}\text { Penyerta+Pen- } \\
\text { yulit Kelas III }\end{array}$ & 3 & 6 & 66.182 .799 & 82.969 .900 & 55.609 .279 & 52.838 .999 & 45.814 .708 & $119,01 \%$ & $125,25 \%$ & $144,46 \%$ & $149 \%$ & $157 \%$ & $181 \%$ \\
\hline
\end{tabular}


Disamping itu, nilai investasi dan gaji pegawai memegang peranan yang cukup besar melihat adanya penurunan nilai cost of treatment pada tiap kelompok CAD berdasarkan clinical pathway.

\section{Kesimpulan dan Saran Kesimpulan}

Ada perbedaan cost recovery rate (CRR) tarif INACBG's dan tarif rumah sakit pada kasus CAD dengan PCI dimana CRR tarif rumah sakit pada severity level I dan II dengan utilisasi stent 1-4 lebih baik dari CRR INA-CBG's karena tarif RS memperhitungkan penambahan jumlah stent pada setiap tindakan PCI sedangkan tarif INA-CBG's tidak memperhitungkan penambahan stent tersebut. Tetapi pada severity level III dengan utilisasi stent sampai dengan 2 nilai CRR INA-CBG's lebih baik dari CRR RS karena tarif INA-CBG's terhadap tindakan PCI di severity level III cukup tinggi melebihi COT, namun jika utility stent lebih dari 2 maka CRR sudah turun dibawah angka $100 \%$. Ini berarti nilai stent sangat berpengaruh dalam menetukan nilai COT pada tindakan PCI bagi pasien CAD.

\section{Saran}

Perlu dilakukan evaluasi metode penghitungantarif INA-CBG's yang berdasarkan metode case base rate, agar menggunakan pendekatan cost of treatment berdasarkan clinical pathway, sehingga besaran biaya yang dikeluarkan untuk penyakit tersebut sudah dipertimbangkan sepenuhnya. Diharapkan adanya perbedaan pengkodingan dan tarif terhadap tindakan kardiovaskuler perkutan berdasarkan utilisasi stent pada masing-masing severity level dan kelas rawat.

\section{Daftar Pustaka}

Adisasmito, (2008), Kebijakan standar pelayanan medik dan diagnosis related group (drg), kelayakan penerapannya di Indonesia Fakultas Kesehatan Masyarakat Universitas Indonesia.

Budiarto,Wasis dan Sugiharto,Mugeni, Biaya Klaim INA-CBGs Dan Biaya Riil Penyakit Katastropik Rawat Inap Peserta Jamkesmas Di Rumah Sakit Studi Di 10 Rumah Sakit Milik Kementerian Kesehatan Januari-Maret 2012, Buletin Penelitian Sistem Kesehatan - Vol. 16 No. 1 Januari 2013: 58-65

Casto \& Clayman, (2006). Principles of Healthcare Reimbursement, American Health Information Management Association, 5-10.
Darmawan A, (2010). Penyakit jantung koroner. Yogyakarta: Fakultas Kedokteran Universitas Muhammadiyah.

Dewi,I. Maulina, (2014)., Price Analysis Tarif Rumah Sakit Dan Tarif INA-CBGs Pada Tindakan Herniotomy Kelas III Dengan Perhitungan Cost of treatment Berbasis Clinical pathway Di Rumah Sakit PMI Bogor Tahun 2014. Tesis, FKM UI, Depok

Djunadi,Purnawan, 2014, Jaminan Kesehatan Nasional,Jalan masih panjang, Jurnal Kedokteran Indonesia, Medika, No.2 Tahun ke XI, Jakarta

Dody Firmanda, Clinical pathways Kesehatan Anak, Sari Pediatri, Vol. 8, No. 3, Desember 2006: 195 $-208$

Djasri, Hanevi,2014, Langkah Penyusunan Clinical pathway, Workshop Penyusunan Clinical pathway dan Perhitungan Cost of Care di RSUD Sampit,2014

Evolution of Drugs (updated). Journal of AHIMA (American Health Information Management Association.) Updated April 2010, bielby, (2010). http://library.ahima.org/xpedio/groups/public/ documents/ahima tanggal 21 Februari 2015

Harun S, Alwi I, (2006). Infak Miokard Akut Tanpa Elevasi St. In Buku Ajar Ilmu PenyakitDalam. 4th ed. Jakarta: Pusat Penerbitan Departemen Ilmu Penyakit Dalam. P:1626

Hospital Payment Systems Based On Dignosis Related Groups; Experiences In Low and Middle-Income Countries; Inke Mathauera \& Friendrich Wittenbecherb; Bulletin World Health Organization

Majid, Abdul, (2007) Penyakit jantung korner Patofisiologi, Pencegahan dan Pengobatan TerkiniPidato pengukuhan Guru Besar., Universitas Sumatera Utara

Muchlis,Achmad,(2014) Cost Shifting bedah Appendiktomi di Rumah Sakit Umum Tangerang,

McPhee et al, 2007, Current Medical Diagnosis and Treatment 2007, Forty Sixth Edition, McGraw-Hill Companies

Mulyadi, Activity Based Costing - System, edisi 6 cetakan ke 2, (2007). UPP STIM YKPN Yogyakarta

Nelwan, Ester Karakteristik Individu Penderita Penyakit Jantung Koroner Di Sulawesi Utara Tahun 2011, Fakultas Kesehatan Masyarakat Universitas Sam Ratulangi Manado

Paruntu, Svetlana, Tesis analisis cost arewness dan cost monitoring untuk efisiensi biaya pelayanan 
di sub departemen radiologi rumkital dr. Mintohardjo (studi kasus: pelayanan thoraks ap/pa foto), FKM UI program KARS, (2012).

Putra, Ryryn,et al (2011), Analisis Biaya Satuan (Unit cost) Perjenis Tindakan Berdasarkan Relative Value Unit (Rvu) Pada Bagian Persalinan Rsud Ajjapange Kabupaten Soppeng Tahun 2011, Jurnal AKK, Vol 2 No 1, Januari 2013, hal 35-41 Setiaji, Hendadi (2006) Analisis Biaya Pelayanan Rawat Inap Di Ruang Vip Cendrawasih RSUD Dr. Soeselo Kabupaten Tegal Tahun 2006,Tesis, FKM UNDIP Semarang

Sugiyarti et al, (2013). Analisis Biaya Satuan Dengan Metode Activity Baed Costing studi kasus di poli mata RSD Balung Kabupaten Jember, Jurnal Pustaka Kesehatan Volume 1, 2013.

Suryawati, C, (2008). Bahan kuliah inflasi biaya kesehatan- fkm-mikm Universitas Diponegoro, Semarang. www.eprints.undip.ac.id tanggal 11 Februari 2015

Textbook of financial cost and management account- ing, periasamy, p, (2010). Global media, Himalaya publishing house, India

Thabrany, Hasbullah, (2014). Jaminan Kesehatan Nasional, PT. Raja Grafindo Persada

Tribowo, Anang (2014) Perbandingan Tarif InaCBGs dengan Tarif RS disampaikan pada Seminar Pencegahan Fraud dan Peningkatan Mutu Layanan Kesehatan di Rumah Sakit Pada Era Jaminan Kesehatan Nasional pada tanggal 20 November 2014 di Auditorium RS RK Charitas

Trisnantoro,L,2009, Memahami Penggunaan Ilmu Ekonomi dalam Manajemen Rumah Sakit, Cetakan keempat, Gadjah Mada Universtity Press. Yogyakarta

Wakefield, John.Patient Safety and Quality Improvement Service, Center for Health Care Improvement, Queensland Version 3, 1,2012)

Zelman, Et Al, (2004).Financial management of health care organizations, an introduction to fundamental tools, concepts, andApplications, Blackwell Publishing, 2004, Second Edition. 